\title{
Economic Liberalisation and Its Socio-Economic Consequences in India, 1966-1996: With Reference to the Japanese Experience of Liberalisation
}

\author{
Simon James Bytheway
}

Abstract

Against the present-day rhetorical backdrop of globalisation, and the apparently "revolutionary" nature of information technology, the following paper strives to recount and reconsider the Indian experience of economic liberalisation in the thirty-year period from the introduction of economic liberalisation and deregulatory reform in 1966, to the fall of the Narasimha Congress government in the general elections of 1996. Particular attention is paid to the role of the state in the context of post-colonial India, and how Congress (I) - under the leadership of Indira Gandhi introduced economic liberalisation, with the intention of easing poverty, to such an extent that by the end of the 1980s liberalisation, under the banner of New Economic Policy, had allowed India to realise unprecedented economic growth. The legacies of India's economic liberalisation, however, deserve careful analysis. Economic growth engendered by liberalisation led to India becoming deeply indebted to foreign creditors, and would prove itself to be unsustainable. So much so that by the time Narasimha Rao came to power, in June 1991, India was on the verge of financial crisis, and was forced to seek IMF assistance. Under the auspices of the green revolution and then economic liberalisation, IMF and World Bank tutelage appeared to have sharpened the divisions amongst Indian society to such an extent that the Indian polity was in danger of failure or partial collapse. Given the magnitude and nature of India's socio-economic problems, perhaps lessons could have been learnt from the example of Japan, and how it extricated itself from an externally driven agenda of economic liberalisation.

Keywords: Economic Liberalisation, Deregulation, Denationalisation, Market, State, New Economic Policy (NEP), World Bank and International Monetary Fund (IMF).

\section{Introduction}

In attempting to discuss the origins, development, and impact of economic liberalisation upon the Indian polity, we must first endeavour to define what is meant by the term "economic liberalisation". While such a definition is problematic, we may reflect that in its simplest form, economic liberalisation is the process by which the means of production are relinquished by the state in favour of the market. Expressing the definition in such rudimentary form reveals that the meaning of economic liberalisation derives from the wider ideological debate concerning which mode of economic organisation best serves society. Over the time 


\section{Simon James Bytheway}

which spans the wider economic debate, the balance of opinion concerning the relative abilities and efficiencies of the rival, state and market, modes of economic organisation has swung from side to side. At present, on a global scale, the balance appears to have turned rather sharply against those in favour of the state mode of economic organisation. ${ }^{1}$

The processes of economic liberalisation and deregulation are central components of the global propensity towards "marketisation"; with the assimilation of India and China being at its centrepiece. Underlain by neoclassical economic theory, the concept of liberalisation has been imbued with many meanings. ${ }^{2}$ In an extended sense, liberalisation advocates minimal government participation in economic activity, although the term liberalisation is occasionally used in ways which imply rigorous state intervention; for example, the introduction of tariffs to replace direct discretionary price controls (that is, quotas). In addition, liberalisation is often associated with restricted areas of economic operation, such as the liberalisation of trade, imports, capital movements, industrial policy, or foreign exchange. Yet, liberalisation in its broadest sense may be defined as the process whereby

(1) state's control over the economic process is reduced, in deference to the operation of the market, or market-based mechanisms (Guha, 1990, pp.1-3).

\section{Post-Colonial India and the Role of the State}

In the context of post-colonial India, economic policies that facilitate economic liberalisation and deregulation represent a clear departure from the principles of the Indian Constitution, which requires the state to direct its policies in such a way as to secure the right of all people to an adequate livelihood. Thus, with emphasis on the under-privileged, the state is to provide the right to employment, education, and public assistance to disadvantaged or - unemployed persons. As the first plan stated,

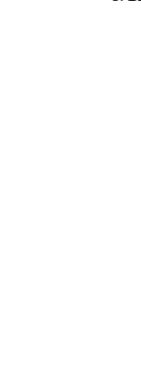

...whether one thinks of the problem of capital formation...or the overall requirement of the production forces and class relationships within society one comes inevitably to the conclusion that a rapid expansion of the economic and social responsibilities of the state will alone be capable of satisfying the legitimate expectations of the people (Behara \& Chandrasekhar, 1988, p.29).

Therefore, the state was to play the dominant role in a mixed economy, where basic and heavy industry were in the public sector, in order to prevent an excessive accumulation of economic power amongst a few private enterprises (Bhattacharya, 1989, pp.150-1).

In post-colonial India's economic development, the role of the state was paramount for approximately the first twenty years. The role of the state began to change, however, with the introduction of economic liberalisation and deregulatory reform (associated with the acceptance of qualified drought relief assistance from the government of the United States of America (US), and the International Monetary Fund (IMF) in 1966. The failure of the 
monsoon in that year, and the severe drought that ensued, found the Indian Congress government (with its newly appointed leader, Indira Gandhi) desperate to finance food imports and cover the balance of its trade deficit. With the food crises, high inflation, a downturn in the global economy, ${ }^{3}$ and an unstable, formative government, India was clearly vulnerable to US, World Bank, and IMF pressure. Thus, by the end of 1966 the Congress regime had withdrawn from its socialist goals; the rupee was devalued (a serious blow against the drive for import substitution), food imports were liberalised, and the first delicensing of industry occurred (Behara \& Chandrasekhar, 1988, pp.38-40).

India's first tentative moves towards liberalisation were eclipsed by the elections of 1967 , and the development of the Fourth Five-Year Plan (1967-1972). In the Fourth Five-Year Plan small and marginal farmers, in reality selected "progressive" farmers (in irrigated regions), were to receive special agricultural assistance (Datta-Chaudhuri, 1990, p.14). Other measures of the plan included the abolition of privy purses for the former princely rulers, and the nationalisation of commercial banks. ${ }^{4}$ Despite the socialist rhetoric, planned economic development of the Indian economy plainly failed to eradicate the scourge of poverty, which afflicted upwards of 50 percent of the Indian population. Against such a backdrop, with growing resentment and restlessness amongst the poor, Congress was in danger of being voted out of government (Kurien, 1994, p.92).

\section{Congress, the New Economic Policy and Liberalisation in Ascent}

Confronted by the prospect of electoral defeat in 1972, Congress (I) ${ }^{5}$ under the leadership of Indira Gandhi, appealed to the mass of India's constituency and campaigned with the slogan and promise of garibi hatao (the eradication of poverty), while simultaneously promoting economic liberalisation. Winning the 1972 election with a substantial majority in the Federal Parliament, and with state governance by the Congress party, or parties generally sympathetic to the social platform of Congress, there was every reason to expect the introduction of major changes in economic policies designed to assist the poorest members of Indian society. ${ }^{6}$ As the elimination of poverty was an explicit objective of the Fifth Five-Year Plan (1972-1977), ${ }^{7}$ the inability of the government to deliver on its promises in the election contributed to renewed discontent and agitation in the mid-1970s, which, in turn, led to almost two years of emergency rule, and the defeat of Congress (I), in 1977 (Kurien, 1994, p.93).

The return to power of Congress (I) party, in early 1980, marked a new stage in the development of liberalisation and deregulatory policy in India. The economic policies of the last two decades had failed to deliver sustained growth and provide the most basic needs of India's poor. ${ }^{8}$ Therefore, in the Sixth Five-Year Plan (1980-1985) the issues of growth and poverty were separated; growth was to be the responsibility of those with resources and capital, and the elimination of poverty would be tackled by the state in special, targeting programs (that is, state profits were to be privatised and private losses socialised). Thus, the primary objective of state policy was to relinquish control of the forces of production, in 


\section{Simon James Bytheway}

favour of the market. For example, import restrictions were lifted according to the emerging patterns of production, while the determination of priorities was decided on the basis of demand as expressed by the ability to purchase. What is apparent in the reforms of the early 1980 s is the shift from planning the economy to managing the economy (Kurien, 1994, pp.92-4).

Liberalisation and deregulatory policy was consolidated under Rajiv Gandhi with the introduction of the New Economic Policy (NEP) in the second half of the 1980s. ${ }^{9}$ The primary objective of the NEP was to revive Indian industrial growth by allowing private producers to have greater freedom in production decisions, increasing investment opportunities for Indian and global capital, and providing tax concessions to India's corporations and high income earning groups. ${ }^{10}$ In accordance with the NEP's objective, farreaching deregulatory measures were introduced: the range and level of tariffs was reduced; the licensing requirements of producers were simplified; broad-banding was introduced; scope for private participation in government utilities was introduced; stock markets were Dartly deregulated;11 quantitative import restrictions were abolished; and the obligation _of foreign enterprises to export a component of their output was dropped (ANZ, 1993; Department of Foreign Affairs, 1989, pp.7-10; and Krishnaswamy, 1993, p.22). In addition, the public sector was expanded on an unprecedented scale and substantial salary increases were granted to senior employees in the public sector (Kurien, 1994, pp.94-6).

The above policies were most successful in generating growth within the domestic market, with the production of consumer durables leading the way, achieving annual increases between 8 percent and 22 percent during the first eight years of the decade. ${ }^{12}$ Indeed, the Omassive expansion of domestic industry was largely fuelled by a consumer boom amongst - the affluent members of Indian society who, although a relatively small group within Indian - Society (constituting approximately 20 percent of the population), represent one of the world's biggest consumer markets with over 200 million consumers. Unfortunately, the - growth of industry did not increase the rate of employment growth throughout the 1980s, and the quality of life of the majority of Indians was largely unaffected. Moreover, by 1989 , the rate of industrial growth had fallen to 1.9 percent and the economy in general was "decelerating". Nevertheless, an impressive overall industrial growth rate of 8 percent per annum was achieved throughout the 1980s, augmented by the strong performance of the agricultural sector, ${ }^{13}$ which registered a 5 percent growth rate throughout the same period. ${ }^{14}$

\section{Liberalisation and Its limits}

It must be said that the unprecedented growth achieved by the "New Economic Policies" of liberalisation was underwritten by an enormous increase in public expenditure and government deficit. The total expenditure of the Central Government had increased from approximately Rs 180 billion in the fiscal year of 1979/1980, to a massive Rs 820 billion by 1989/1990 (that is, an almost five-fold rise from Rs 18 thousand crores to Rs 82 thousand crores in a decade). Expenditure of such proportions could only be met by a corresponding 
increase in public borrowing and deficit financing (Kurien, 1994, p.96). In addition, India's balance of trade deterioration, primarily due to the increased cost of petroleum product importation after the second oil-shock in $1979,{ }^{15}$ forced the government of India to negotiate a balance of payment "adjustment" loan with the IMF worth SDR 5 billion ${ }^{16}$ over the four fiscal years from 1980/1981 to 1984/1985 (Datta-Chaudhuri, 1990, pp.25-31).

Having introduced import liberalisation, the government of India, was then able to secure commercial borrowings on an unprecedented scale. For example, less than 1 percent of India's foreign debt was owed to private creditors in 1979/1980; yet by 1986/1987 such debts amounted to 22 percent of India's foreign debt (BM, 1990, pp.1439-40). Commercial borrowings, when combined with development loans, increased from $\$ 18.7$ billion U.S. dollars in 1980, to $\$ 56$ billion U.S. dollars in 1989. Expressed in terms of GNP, external borrowings increased from approximately 10.8 percent of GNP in 1980, to about 21.5 percent of GNP in 1989, while the service of debt, expressed as a proportion of the exports of goods and services, increased from 9.1 percent to 26.3 percent during the same period (Kurien, 1994, pp.96-8). By the end of the 1980s liberalisation had allowed India to realise an unprecedented, if unsustainable, economic growth, at the expense of becoming one of the largest debtor nations in the world.

When the minority Congress (I) government of P.V. Narasimha Rao came to power, in June 1991, the economic implications of the stock market crash of 1987 and the war in Kuwait (increased oil prices and reduced remittances) had placed India on the verge of a balance of payments crisis. The IMF's call for a 20 percent devaluation of the rupee, to correct the balance of payments problem, had induced non-resident Indians and foreign nationals to withdraw $\$ 1.3$ billion U.S. dollars worth of foreign currency from Indian banks. Thus, by the end of June 1991, foreign exchange reserves had experienced an alarming reduction and were only sufficient for two weeks' requirements (Kurien, 1994, pp.100-3). Moreover, inflation had surged into double digits, averaging 13.7 percent for the 1991/1992 financial year (Rao, et al., 1993, p.3). Just three days away from defaulting on loan repayments, the new government turned to the IMF for assistance in meeting its balance of payments, and to attempt to stem the exodus of foreign capital (Basu, 1993, pp.5-6). In accepting the IMF loan as a "stabilisation" measure, it would seem that the Narasimha regime was obliged to accept responsibility for internal "structural adjustments". ${ }^{17}$

The events of 1991 represent a marked consolidation of the policies of economic liberalisation and deregulation. Liberalisation progressed much in the manner as previous Government of India, World Bank and IMF reports suggested that it should. At first, in July, the rupee was devalued by approximately 20 percent in terms of the major international currencies. With a sense of urgency, measures to control the fiscal deficit and money supply were enforced so that the rupee could become fully convertible, and, thus attract foreign investment to India (Krishnaswamy, 1993, pp.36-7). Policy directives abolished industrial licensing for all but the most hazardous and environmentally sensitive industries; licensing requirements for the importation of capital goods and raw materials were abolished; import tariffs were 
substantially decreased; and the import of gold and silver was liberalised (Kurien, 1994, pp.102-4).

Moreover, the marginal rate of personal income tax and corporate tax was restructured and reduced; excise duties were simplified; the banking sector was reformed, and stock market regulations were rationalised. In relation to state owned enterprises "disinvestment" of up to 49 percent of holdings was permitted in selected public sector enterprises, whilst budgetary support was withdrawn from those enterprises making losses. To soften the social impact of the revitalised economic liberalisation and deregulatory measures, a National Renewal Fund (NRF) was created to compensate, retrain, and redeploy those workers negatively affected by the liberalisation of the Indian economy (Rao, et al., 1993, pp.6-11, 19-28).

Ultimately, as the process of economic liberalisation and deregulation accelerated and intensified throughout the 1980s and the 1990s, it generated increasing internal opposition within India. While the July 1991 IMF loan agreement and the World Bank's Structural Adjustment Loan (SAL) of December 1991 was intended to assist India by alleviating its balance of payments crises, reducing the fiscal deficit, and relieving inflation; the opposite happened. Inflation was still a major concern; the balance of payment difficulties were amplified by the increased cost of imported raw material and the influx of luxury goods; and social welfare and infrastructural spending cuts were undermining the viability of politically powerful Indian producers. ${ }^{18}$ Furthermore, trade liberalisation allowed foreign companies and multinationals, eager to secure a place in India's domestic market, to contest domestic producers weakened by the devaluation of the rupee (Chosssudovsky, 1993, pp.385-7). Moreover, acceptance of the Dunkel Draft proposals potentially enabled technologically advanced, internationally oriented, manufacturers to further exploit India's domestic market, particularly in regard to the register of patents, in both agriculture and industry (Chandrashekar \& Chatterjee, 1993, pp.6-21).

\section{A Comparison with the Japanese Experience of Economic Liberalisation}

Was there another way forward for India? Could the introduction, or imposition, of economic deregulation and liberalisation (primarily, as a response to economic and financial crises) have been handled in a more sensitive manner, with greater emphasis on India's long-term needs? At this point, a brief reference to the Japanese experience of economic liberalisation will serve to clarify the divisive nature of the Indian example. First and foremost, it must be said that successive post-war Japanese governments successfully resisted foreign pressure to liberalise the domestic economy until, at least, the mid to late 1960s. The adoption of a program of economic liberalisation became a political necessity, largely as a consequence of the debate surrounding Japan's acceptance of the International Monetary Fund (IMF) Article VIII (trade liberalisation), and subsequent membership to the Organization for Economic Cooperation and Development (OECD) in 1964. Nevertheless, Japan's new liberalisation programme was clearly protectionist: wherever possible, the national economy was to be reserved for Japanese industry. In 1968, Amaya Naohiro, a senior Ministry of International 
Trade and Industry (MITI) bureaucrat and an important architect of Japan's industrial, investment and trade policies put it thus:

It does a nation more harm than good to introduce free competition when the structures of industry and finance provide only a less than satisfactory environment in which free competition can flourish (Ozaki, 1971, p.1080).

And so the stage was set for a clash between the conservative "protective" Japanese nexus of businessmen, bureaucrats and politicians, and revolutionary global forces generated by the world's leading capitalist economy and its multinational corporations.

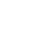

What liberalisation of the Japanese economy did occur, in fact, owes much to years of acrimonious debate between the American automotive industry and Japanese authorities. The Japanese automotive industry was essentially on a path of autonomous development, despite receiving generous technical assistance from American and British manufacturers (particularly during the 1950s years of "special procurements" for the war in Korea). Foreign automobile manufacturers, particularly the American Big Three, were subject to unyielding opposition from the Japanese authorities in their attempts to gain access to the domestic Japanese market. During key IMF, trade liberalisation, and OECD negotiations in the 1960s, however, the Japanese government was forced to release programmes ostensibly aimed at liberalising areas of the automotive industry. International, particularly the US, reaction to these liberalisation programmes was "decidedly negative". In fact, American manufacturers characterised the Japanese government's efforts as being, "evasive manoeuvres designed to gain time and postpone a real liberalisation" (Adams and Hoshii, 1972, p.259). Nevertheless, the Japanese authorities did capitulate to key US demands (cf. Maurice Stans), and the liberalisation process was reinvigorated, as evidenced by the relatively large number of joint ventures established between American and Japanese firms in the period from 1969 to $1971 . .^{19}$

Clearly, any comparison between the Indian and Japanese experiences of liberalisation is, necessarily, limited in nature. Still, it is interesting to note that the start of Indian and 


\section{Simon James Bytheway}

Japanese de-licensing and deregulation (in more general terms, the processes of economic liberalisation) were contemporaneous, despite very different reasons for their introduction in each country. Critically, by the late 1970s Japan (approaching the pinnacle of its economic performance) was able to extricate itself from an externally driven agenda of liberalisation, and adopt a national policy of so-called "internationalisation". Arguably Japan became, owing to its own state-instigated efforts, "international"; that is, conformed to established intra-national standards of the modern, industrialised (and Western) economies. ${ }^{20}$ In the case of India, however, financial weakness and fundamental trade imbalances in the late 1980s and early 1990s denied its government the opportunity to pursue a similar stateinstigated course of action, and, consequently, we are obliged to discuss the subsequent socio-economic failures of liberalisation in India.

\section{The Legacies of India's Liberalisation}

The impact of economic liberalisation and deregulation upon India's organised and (1) unorganised labour forces is another aspect of what was becoming an ongoing debate _on the nature and implications of liberalisation. Of particular concern to labour was the denationalisation of the public sector, the exit policy for both public and private units, the provision of unlimited access to multinationals, and the export orientation of the agricultural and industrial bases (Centre of Indian Trade Unions (CITU), 1994, pp.2-3). Within the first five years of the introduction of public sector "denationalisation" an estimated 4 to 8 million public and private workers, in an organised workforce of 26 million workers, were to be rationalised as a result of the liberalisation program (Chosssudovsky, 1993, p.385). The National Renewal Fund (NRF), the World Bank's planned "social security net", could not hope to compensate or placate those workers displaced by the new concessions - extended to private producers (Centre of Indian Trade Unions (CITU), 1992, p.1). It would - appear that India's constitutional goal of social development through self-reliance had been compromised, despite the objections made by those parties of the broad "left front", led by - the Communist Party of India (Marxist) (CPI-M).

으

The implications of the "liberalisation" of India's labour laws upon the lives of India's casual and seasonal agricultural workers was also a cause of consternation. ${ }^{21}$ Rather than extending the ability of labour laws to protect the unorganised labour force, deregulation threatened to reinforce despotic social relations. That is, caste-exploitation, semi-slavery, and child labour were set to continue, as several hundred million Indians (marginal farm workers, small traders, artisans, and their dependants) eked out an existence on less than one American dollar a day. Rising domestic prices, in general, and a greater than 50 percent increase in the price of rice and wheat (since the reforms of July 1991), combined with decreased labour demand in both rain-fed and irrigated agriculture to push large sectors of the rural population closer towards starvation (Chosssudovsky, 1993, p.386). Perhaps the cruellest irony of liberalisation policy was that India's rice exports increased, largely as a consequence of the decrease in domestic food consumption, during this period.$^{22}$ Moreover, the scheduled phasing out of fertiliser and food subsides only threatened to aggravate the 
anger, discontent and misery experienced in the increasingly politicised atmosphere of rural India in the $1990 \mathrm{~s} .{ }^{23}$ While it is difficult to ascertain the number of people suffering from under-nourishment or starvation from the time of Independence in 1947 to the 1990s, "food security" was (and is) vital for India, and liberalisation invariably threatened to compromise it. $^{24}$

Another disturbing feature of the economic liberalisation and deregulation of the Indian economy is that the process of liberalisation itself sharpened divisions amongst Indian society to such an extent that the Indian polity is in danger of failure or partial collapse. Under the auspices of the green revolution, and then economic liberalisation, IMF and World Bank tutelage has further polarised Indian society, and appears to have created the preconditions of rupture within the Indian union. The consolidation of economic liberalisation, as an austerity program, exacerbates the present tensions between the centre and the states, especially those states of Assam, Kashmir, and the Punjab, where there is the threat of succession (Mayer, 1991, pp.19-24). Moreover, the increased economic hardship and poverty experienced by most Indians, as a result of economic liberalisation, has heightened the awareness of many Indians to religious, ethnic, and regional disparities, providing for the growth of Hindu and Islamic fundamentalism. In such an environment the Hindu chauvinist Bharatiya Janata Party (BJP), the main opposition party, appeared to have gained significant electoral support. Ironically, BJP gains were won despite the fact that they kept the Narasimha regime afloat by supporting the IMF-World Bank programme on the floor of the Lok Sabha (Puri, 1990, pp.15-6). With the Congress (I) party rapidly losing support, particularly as food prices increased, Congress (I) members were deeply divided on the issue of economic policy. Furthermore, the Nationalist Front and the Leftist Front (led by the CPI-M) feared that the demise of Congress (I) might lead to the rise of the BJP, if they could not take over government in their own right (Chosssudovsky, 1993, p.387). As it turned out, their fears were briefly realised in 1996, and later from 1998 to 2004, with the subsequent formation of two BJP-led governments.

\section{Conclusion}

In defining economic liberalisation and then analysing the origins, development, and impact of economic liberalisation upon the Indian polity, the realisation that such reforms derive from a particular diagnosis of the structural problems of the Indian economy is fundamental. Given the chronic nature of India's socio-economic crisis, the "cure" of liberalisation and deregulation, widely implemented by the IMF and World Bank throughout the world, ${ }^{25}$ favoured those who owned capital and the means of production in India. While those that are already living in poverty, barely able to feed themselves, shouldered the burden of "liberal economic reform". With so much at stake, it is not surprising that the Indian political system was in turmoil over the effectiveness and intent of economic liberalisation (Vaidyanathan, 1995, pp.72, 95). In contrast to Japan, India was unable to maintain its financial independence at key junctures in its 1966-1996 history, although both countries shared a common initial trajectory thrown up by the liberalisation campaigns of the 1960s. 


\section{Simon James Bytheway}

Perhaps the resistance economic liberalisation engendered as its policies took hold will remind the IMF and the World Bank of what Joan Robinson once said, "All economic answers are only political questions." 26

\section{End Notes}

See Guha (1990, pp.1-3). The state-sponsored "bailouts" which followed the fall of the Lehman Brothers, in September 2008, confirm that the (much maligned) role of the state remains crucial to the performance of the mixed economies of the "capitalist" West.

For a neoclassical explanation of India's economic development see Bhagwati (1993). As a counterpoint, for critiques of neoclassical economic ideology see Patnaik (1993), and Ranadive (1994, pp.2-13).

Explanation of the significance of global economic cycles can be found in Mandel (1973).

It should also be noted that there were almost no innovations in the industrial sector owing to the failure of the industrialisation programs during the eras of the Second and Third Plans. See Datta-Chaudhuri, (1990).

In the late 1960s the Congress Party had split into two separate parties, the Congress (O) of Moraji Desai, and the Congress (N) later (I) of Indira Gandhi.

For a more detailed explanation of India's "disturbingly sluggish" economic progress see Cassen (1978, pp.215-22).

Indeed, preparatory documents suggested that the consumption of the top 30 percent of Indian society was to be frozen, thereby facilitating the transfer of resources to the bottom 30 percent of society. See Kurien (1992, pp.365-9).

For example, those households without access to safe drinking water were calculated to be 61.82 percent of India's total population, likewise households without electricity 73.81 percent, households without a literate member 32.96 percent, and so on. See Basu (1993, p.4).

Rajiv Gandhi replaced his mother as the leader of Congress (I) in 1984, after her assassination by Sikh bodyguards, in retaliation for her ordered violation of the Sikh's Golden Temple in Amritsar.

The major policy reversal, in regards to the operation of foreign capital, was one of the centre points of the liberalisation policy of the Indian government under Rajiv Gandhi. Foreign participation was liberalised to the extent that 100 percent foreign ownership was tolerated in export production companies. See Behara and Chandrasekhar (1988, p.210). 
Economic Liberalisation and Its Socio-Economic Consequences in India, 1966-1996: With Reference to the Japanese Experience of Liberalisation

Some observers have referred to the same process as being one of "permeable insulation" and stress the Japanese government's "pragmatic utilization of new rules and circumstances" which continue to promote domestic firms engaged in international competition, and to protect them against the same competition. See Schaede and Grimes (2003, pp.6-8), and particularly "Permeable Insulation and Japan's Managed Globalization", in Schaede and Grimes (2003, p.243).

It must be remembered that India's economy was agriculturally based, with something like 67 percent of the Indian population involved in agricultural production. The relative importance of agriculture (in terms of percent of GDP), however, has steadily decreased from over 50 percent in the 1950s to around 30 percent in the 1990s. At the same time, there have been significant improvements in agricultural food grain production since independence, from 


\section{Simon James Bytheway}

52.2 million tonnes in $1951 / 1952$ to 180 million tonnes in $1992 / 1993$, primarily owing to the intensification (or "green revolution") of Indian agriculture. See B.H. Farmer (1986, pp.17599).

22 For a detailed agenda of the proposed "liberalisation" of agriculture see Pursell and Gulati (1993).

For further discussion of the issues relating to food and fertiliser subsidies see Bhide (1993).

It is speculated that the scale of famines in twenty-first century India will be without historical parallel. See Chosssudovsky (1993, p.386).

For the South American experience of liberalisation see Bovkil (1990, pp.160-86).

See Ranadive (1994, p.3).

\section{References}

Adams, T.F.M., \& Hoshii, I. (1972). A financial history of the new Japan. Tokyo: Kodansha.

ANZ. (1993, July). India's economic liberalisation. Symposium on India's Economic Liberalisation, Melbourne.

Argarwal, A.N., et al. (1990, January 15). A momentous decade. India Today.

Basu, K. (1993, July). Structural reform in India, 1991-1993: Experience and Agenda. Symposium on India's Economic Liberalisation, Melbourne.

Behara, M., \& Chandrasekhar, C.P. (eds.) (1988). India in an era of liberalisation. London: Euromoney.

Bhagwati, J. (1993). India in transition: Freeing the economy. Oxford: Clarendon Press.

Bhattacharya, D. (1989). Growth and distribution in India. In Journal of Contemporary Asia, 19 (2), 150-166.

Bhide, S. (1993, July). Liberalisation and agriculture: The case of fertilizer and food subsides. Symposium on India’s Economic Liberalisation, Melbourne.

BM. (1990). Seeking salvation in foreign private investment. Economic and Political Weekly, 25 (27), 1439-40. 
Economic Liberalisation and Its Socio-Economic Consequences in India, 1966-1996: With Reference to the Japanese Experience of Liberalisation

Bokil, S. V. (1990). A Study of the liberalization in the Southern cone countries of Latin America: Lessons for India. Economic Liberalization, Industrial Structure and Growth in India. Delhi: Oxford University Press, 160-86.

Bytheway, S. J. (2010). Liberalization, internationalization, and globalization: Charting the course of foreign investment in the finance and commerce of Japan, 1945-2009. Japan Forum, 22 (3-4), 433-65.

Cassen, R. (1978). India: Population, economy and society. London: Macmillan.

Centre of Indian Trade Unions (CITU). (1992). Fiscal and economic policies criticised. The Working Class: The Monthly Journal of the CITU, 22 (6), 1.

(1)

Centre of Indian Trade Unions (CITU). (1994, November). Trade union rights and labour. standards in the new global economy: Developing a grass root response. Third Indian Ocean Regional Trade Union Conference, Report on India 2-3.

Chandrashekar, B. K., \& Chatterjee, S. (1993). The dunkel draft: Design for disaster, Bangalore: Navakarnataka.

Chossudovsky, M. (1993). India under IMF Rule. Economic and Political Weekly, 28 (10), $385-7$.

Datta-Chaudhuri, M. (1990). The background to the current debate on economic reform: Oilshocks, recession in world trade and adjustment problems for the Indian economy. Economic liberalization, industrial structure and growth in India. Delhi: Oxford University Press, 9-37.

Department of Foreign Affairs. (1989). Trade and commercial development program for Australia. Canberra: Publishers.

Department of Foreign Affairs. (1989). India: Country economic brief. Canberra: Publishers.

Farmer, B. H. (1986). Perspectives on the "Green Revolution" in South Asia. Modern Asian Studies, 20 (1), 175-99.

Guha, A. (1990). Introduction. Economic liberalization, industrial structure and growth in India. Delhi: Oxford University Press, $1-8$.

Guha, A. (1990). The political economy of liberalization. Economic Liberalization, industrial structure and growth in India. Delhi: Oxford University Press, 38-50. 


\section{Simon James Bytheway}

Kochanek, S. A. (1987). Briefcase politics in India: The congress party and the business elite. Asian Survey, 27 (12), 1278-301.

Krishnaswamy, K. S. (1993). GATT negotiations and the dunkel draft. The dunkel draft: design for disaster. Bangalore: Navakarnataka, 22-38.

Kurien, C.T. (1992). The economy: An interpretive introduction. New Delhi: Sage.

Kurien, C.T. (1994). Global capitalism and the Indian economy. New Delhi: Orient Longman.

Mayer, P. (1991). Which way does the wind blow in a Cyclone? Longer-term trends in rural India. IOCPS Briefing Paper No.1, June 1991, 19-24.

Ninian, T., \& Mathai, P. G. (1985, July 31). New money spinner. India Today, 50-8.

Ninian, T., \& Mathai, P.G. (1985, December 31). Rise of the middle class. India Today, - 70-5.

Ninian, T., \& Mathai, P. G. (1987, October 31). The new millionaires. India Today 40-7.

Ozaki, R. S. (1971). Japanese views on foreign capital. Asian Survey, 11 (11), 1071-83.

Palakunnathu, G., \& Mathai, G. (1985, December 31). Small is beautiful. India Today, 79-82.

$\infty$

Patnaik, P. (1993, July). International capital and national economic policy. Symposium on

India's Economic Liberalisation, Melbourne.

- Puri, B. (1990). Can caste, region and ideology stem Hindu wave. Economic and Political Weekly, 25 (1), 15-6.

Pursell, G., \& Gulati, A. (1993, July). Liberalising Indian agriculture: An agenda for reform. Symposium on India's Economic Liberalisation, Melbourne.

Ranadive, K. (1994). Market, democracy and unequal relation. Economic and Political Weekly, 29 (5), 2-13.

Rao, S., et al. (1993). Mid year review of the Indian economy: 1992-93. Bombay: Centre of Monitoring Indian Economy.

Schaede, U., \& Grimes, W. W. (2003). Introduction: The emergence of permeable insulation. Japan's managed globalization: Adapting to the twenty-first century. New York: M.E. Sharpe, 3-16. 
Economic Liberalisation and Its Socio-Economic Consequences in India, 1966-1996:

With Reference to the Japanese Experience of Liberalisation

Schaede, U., \& Grimes, W. W. (2003). Permeable insulation and Japan's managed globalization. Japan's managed globalization: Adapting to the twenty-first century. New York: M. E. Sharpe, 243-54.

Singh, R., \& Chengappa, R. (1985, December 31). Day of the farmer. India Today, 75-8.

Vaidyanathan, A. (1995), The Indian economy: Crises, response and prospects. New Delhi: Orient Longman. 


$$
\begin{aligned}
& \text { हे } \\
& \text { כ } \\
& \overline{0} \\
& \text { (1) } \\
& \frac{\varepsilon}{\Xi} \\
& \text { ( ) } \\
& \sqrt{\square \quad} \\
& \text { 음 } \\
& \text { 政 } \\
& \text { ع }
\end{aligned}
$$

